\title{
A teoria de Amartya Sen: uma aplicação da abordagem das capacitações e da ideia de justiça à evolução do mercado nacional de trabalho contemporâneo
}

\author{
Ednilson Silva Felipe \\ Universidade Federal do Espírito Santo \\ Juliano Vargas \\ Universidade de Brasília
}

\section{Resumo}

O artigo examina pontos de convergência e de divergência entre a evolução do mercado nacional de trabalho contemporâneo e alguns aspectos socioeconômicos e institucionais pós 1990, via abordagem das capacitações e ideia de justiça de Amartya Sen. Dois períodos são relevantes para essa discussão: a) 1990-2002, em que o Brasil passou por processos que promoveram desregulamentação do mundo do trabalho e reconfiguração do mercado nacional de trabalho; b) 2003-2014, com participação mais efetiva do Estado e da sociedade civil dentro da perspectiva de um mundo do trabalho desregulamentado e de um mercado nacional de trabalho reconfigurado. Resulta dessa análise a observância de que a presença da sociedade e de suas instituições são indispensáveis para uma trajetória de desenvolvimento socioeconômico sustentável, via concretização de políticas públicas que aumentem a liberdade e a igualdade de oportunidades, protejam o tecido social e garantam os direitos individuais e coletivos do trabalho. A teoria seniana é ferramenta conveniente para a interpretação das mudanças do mercado nacional de trabalho, por evidenciar que o País tem longo caminho a percorrer no que se refere à promoção da equidade na justiça que favoreça a habilitação qualificada no sistema produtivo.

Palavras-chave: Abordagem das Capacitações. Desenvolvimento Socioeconômico. Ideia de Justiça. Mercado Nacional de Trabalho. Sen.

The theory of Amartya Sen: an application of the capabilities approach and the idea of justice to the contemporary evolution of the national labor market

\begin{abstract}
The paper examines points of convergence and divergence between the evolution of the contemporary national labor market and some post 1990 socioeconomic and institutional issues, via capabilities approach and idea of justice of Amartya Sen. Two periods are relevant to this discussion: a) 1990-2002, in which Brazil went through processes that promoted deregulation of its world of work and reconfiguration of its national labor market; b) 2003-2014, with a more effective participation of the state and the civil society, from the perspective of a deregulated labor world and a reconfigured national labor
\end{abstract}


market. As a result of this analysis it is possible to assert that the presence of society and its institutions are indispensable to a path of sustainable socioeconomic development, through concretion of public policies that increase the freedom and equal opportunities, protect the social fabric and guarantee the individual and collective labor rights. The senian theory is a convenient tool for the interpretation of changes in the national labor market, showing that the country has a long way to go with regard to the promotion of equity in justice that encourages a qualified enabling in the production system.

Keywords: Capabilities Approach. Socioeconomic Development. Idea of Justice. National Labor Market. Sen.

\section{La teoría de Amartya Sen: una aplicación del enfoque de las capacidades y de la idea de justicia a la evolución del mercado nacional de trabajo contemporáneo}

\section{Resumen}

El artículo examina puntos de convergencia y divergencia entre la evolución del mercado nacional de trabajo contemporáneo y algunos aspectos socioeconómicos e institucionales después de 1990, a través del abordaje de las capacidades y la idea de justicia de Amartya Sen. Dos períodos son relevantes para esta discusión: a) 1990-2002, en que Brasil pasó por procesos que promovieron desregulación del mundo del trabajo y reconfiguración del mercado nacional de trabajo; b) 2003-2014, con participación más efectiva del Estado y de la sociedad civil dentro de la perspectiva de un mundo del trabajo desregulado y de un mercado nacional de trabajo reconfigurado. De este análisis se desprende que la presencia de la sociedad y de sus instituciones son indispensables para una trayectoria de desarrollo socioeconómico sostenible, a través de la aplicación de políticas públicas que incrementen la libertad y la igualdad de oportunidades, protejan el tejido social y garanticen los derechos individuales y colectivos del trabajo. La teoría seniana es una herramienta conveniente para la interpretación de los cambios del mercado nacional de trabajo, por evidenciar que el país tiene largo camino por recorrer en lo que se refiere a la promoción de la equidad en la justicia que favorezca la habilitación cualificada en el sistema productivo.

Palabras clave: Abordaje de las Capacitaciones. Desarrollo Socioeconómico. Idea de Justicia. Mercado Nacional de Trabajo. Sen.

\section{INTRODUÇÃO}

O Brasil é complexo do ponto de vista socioeconômico. Devido a suas idiossincrasias, historicamente há obstaculização à melhor performance global no que se refere às oportunidades e às liberdades de desenvolvimento individual e coletivo. Seu mundo do trabalho é um exemplo dessa realidade. As contínuas alterações conjunturais e estruturais ocorridas desde o fim da década de 1980 no mercado nacional de trabalho têm demandado esforços das instituições e da sociedade como um todo para que seja favorecida a habilitação qualificada dos cidadãos que participam do sistema produtivo.

Entre 1990 e 2014, o País passou por inúmeras transformações, tais como: a abertura comercial e financeira, a reestabilização econômica e a maior inserção internacional. Esses fatores afetaram profundamente e de maneiras diversas as relações trabalhistas, reconfigurando-as. No entanto, a combinação desses eventos não reverberou em superação da prática extensiva do subemprego, da precarização laboral e da própria existência humana. 
É nesse contexto que serão utilizadas a ideia de justiça e a abordagem das capacitações formuladas por Amartya Sen, com o propósito de examinar as principais mudanças econômicas e institucionais ocorridas entre 1990 e 2014 e seus efeitos no mercado nacional de trabalho contemporâneo. Essencialmente, as obras senianas intituladas Desenvolvimento como Liberdade (1999), Ética e Economia (2005) e A Ideia de Justiça (2009) propõem aproximar duas visões que, aparentemente, possuem irremediável antagonismo: a igualdade e a liberdade. Isso mediante promoção da equidade e da justiça social. As contribuições do pensador indiano expõem as limitações do sistema de livre mercado (ou mercado autorregulado) e de como suas falhas podem implicar em prejuízos às potencialidades individuais e ao desenvolvimento socioeconômico em geral.

Suas pesquisas oferecem um enfoque sistêmico e multidisciplinar que abrange os campos de estudo da Economia, das Ciências Sociais, da História, do Direito e da Filosofia. Essa visão considera as especificidades históricas de cada período, permitindo seu emprego na avaliação de inúmeros aspectos do mercado nacional do trabalho. Nesse processo, o trabalho - como atividade humana compõe parte importante do todo individual e social. Entende-se que essas são características essenciais constituintes também deste estudo.

A partir de um prisma descritivo e analítico, o artigo está estruturado em três seções. Na primeira, são expostos os argumentos de Sen a respeito da abordagem das capacitações e da ideia de justiça. Entremeadas por essa concepção teórica, as seções seguintes apresentam discussões de duas fases fundamentais': a) o intervalo 1990-2002, em que o Brasil passou por processos que promoveram desregulamentação do mundo do trabalho e reconfiguração do mercado nacional de trabalho; b) o interregno 2003-2014, com participação mais ativa do Estado e da sociedade civil em relação ao período anterior, dentro da perspectiva do mundo de trabalho desregulamentado e do mercado nacional de trabalho reconfigurado.

\section{A CONCEPÇÃO TEÓRICA DE SEN: A ABORDAGEM DAS CAPACITAÇÕES E A IDEIA DE JUSTIÇA}

As contribuições de Amartya Sen às Ciências Econômicas abarcam distintos seguimentos. Vão desde temas relativos à escolha social, à economia do bem-estar e à escolha racional até o crescimento e o desenvolvimento econômico. Além da esfera analítica exclusivamente acadêmica, destaca-se seu envolvimento em assuntos práticos relacionados à pobreza e à desigualdade. Duas teses defendidas pelo autor são fundamentais para o entendimento do conjunto de sua obra: a abordagem das capacitações e a ideia de justiça.

\subsection{A abordagem das capacitações}


A abordagem das capacitações de Sen reflete as inúmeras combinações de funcionamentos que as pessoas podem atingir. Esses funcionamentos traduzem-se por estados e atividades que as pessoas valorizam em suas vidas. A capacitação alude à liberdade individual da escolha por um modo de viver. Capacidade pessoal equivale à liberdade pessoal, sendo um conceito que se define pela noção de potencialidade (SEN, 1999).

Assim, o autor argumenta que as capacitações das pessoas devem ser equiparadas, proporcionando condições que favoreçam aos indivíduos conseguirem atingir seus objetivos essenciais. Ele embasa sua interpretação no reconhecimento da potencialidade como uma liberdade, "principal fim e principal meio do desenvolvimento. O desenvolvimento consiste na eliminação de privações de liberdade que limitam as escolhas e as oportunidades das pessoas de exercer ponderadamente sua condição de agente" (SEN, 1999, p. 10).

A condição de agente de cada pessoa é inevitavelmente limitada pelas oportunidades sociais, políticas e econômicas de que esta dispõe. O agente é o indivíduo que atua e gera mudança, tendo sua prática apreciada em termos de seus próprios objetivos e valores. Há complementaridade entre a condição de agente individual e as disposições sociais. Logo, o bem-estar social é o objetivo a ser atingido, pois é esse o sentido das escolhas rumo ao desenvolvimento. Deve-se reafirmar as relações sociais e valorizá-las, conjugando o mercado com a regulação institucional das relações econômicas pela sociedade (SEN, 1977, 1999).

Nesse sentido, Sen aproxima duas visões que aparentemente possuem irremediável antagonismo: igualdade e liberdade, enfatizando o papel da participação da sociedade civil, autodeterminação e livre arbítrio como forma de desenvolvimento de um povo, sem confundi-lo com o crescimento econômico da região em que este vive. Assim, o autor evidencia as inúmeras implicações da abordagem das capacitações.

\begin{abstract}
Uma variedade de instituições sociais - ligadas a operação de mercados, a administrações, legislaturas, partidos políticos, organizações não governamentais, poder judiciário, mídia e comunidade em geral contribui para o processo de desenvolvimento precisamente por meio de seus efeitos sobre o aumento e a sustentação das liberdades individuais. A análise do desenvolvimento requer uma compreensão integrada dos papéis respectivos dessas diferentes instituições e suas interações (SEN, 1999, p. 336).
\end{abstract}

Dessa assertiva derivam as noções interdependentes de liberdades instrumentais e substantivas. As primeiras são consideradas no processo social de desenvolvimento e estão intimamente relacionadas às liberdades políticas e econômicas, às oportunidades sociais, às garantias de transparência interpessoal (segurança do convívio público) e à rede de segurança social (SEN, 1999).

Assim, o debate público deve favorecer a expansão das capacidades básicas dos cidadãos, possibilitando que se ouçam as demandas da sociedade (direitos democráticos institucionalizados) e fazendo com que as necessidades sejam conceituadas em suas múltiplas dimensões e não reduzidas à questão da renda. A abordagem das capacitações convém como forma de criar consciência sobre o que é socialmente injusto, isto é, como provisão para a discussão pública. Ademais, dessa conclusão nota-se outra característica de Sen: ser crítico à tendência 
prevalente de aferir o sucesso do desenvolvimento com base exclusivamente nas variações do produto interno bruto - PIB (SEN, 1999, 2005, 2009).

Da afirmação das liberdades instrumentais é que podem concretizar-se as liberdades substantivas. Dentre essas últimas, o autor destaca as capacidades de se impedir a desnutrição, a fome, a mortalidade precoce e as liberdades relativas ao acesso à educação/cultura ou à participação ativa na vida política da sociedade. Para isso, o desenvolvimento requer que se removam as principais fontes de privação de liberdade: i) pobreza e tirania; ii) carência de oportunidades econômicas e destituição social sistemática; iii) negligência dos serviços públicos; iv) intolerância ou interferência excessiva de Estados opressivos (SEN, 1999).

Desse modo, a liberdade política ampla deve ser a tônica, em que é importante ao indivíduo ter garantidos seus "direitos a ter direitos". Essa é uma perspectiva de transformação social que busca evitar e eliminar as barreiras que impedem que os indivíduos tenham acesso ao que eles considerem importante para suas vidas. O autor defende a tese de que o atraso econômico se deve predominantemente à privação de liberdades, causada por limitações impostas aos indivíduos no que tange às restrições e impedimentos da melhoria da qualidade de vida e das condições sociais. Dito de outra maneira, a ampliação das liberdades necessita (e geralmente é associada) do aumento de renda e da ampliação dos direitos trabalhistas, do sistema de seguridade social e demais acessos básicos a uma vida digna. Senão, veja-se:

O fato é que essas liberdades e direitos também contribuem muito eficazmente para o progresso econômico [...]. Mas, embora a relação causal seja de fato significativa, a justificação das liberdades e direitos estabelecida por essa ligação causal é adicional ao papel diretamente constitutivo dessas liberdades no desenvolvimento. (SEN, 1999, p. 20).

Essa concepção multidimensional do desenvolvimento constitui-se também em componente da teoria seniana, que propõe: i) combinar a ampliação e a diversificação do mercado com o aumento da oferta de oportunidades sociais; ii) diferentes vias distributivas asseguradoras do acesso a bens públicos pela população carente; iii) subsídios e transferências de renda em complemento ao aprimoramento das capacidades sociais básicas (SEN, 1999).

\subsection{A ideia de justiça}

Nesse ínterim, Sen traz elementos centrais ao debate sob o ponto de vista de sua ideia de justiça. O autor é adepto de arranjos que primam pela observação do comportamento real das pessoas e de suas relações sociais, valorizam as diferenças e consideram a vida que as pessoas são capazes de levar. Para ele, "a justiça está fundamentalmente conectada ao modo como as pessoas vivem e não meramente à natureza das instituições que as cercam" (SEN, 2009, p. 12-13). O institucionalismo transcendental (com tendência "contratualista") é obstáculo à remoção das injustiças, por concentrar-se nas utopias de justiça perfeita. Já a comparação focada nas realizações favorece a análise racional das assimetrias produtoras de injustiças na vida das pessoas reais, levando em consideração também fatores não racionais como os anseios dos indivíduos (SEN, 2005, 2009). 
A partir dessa concepção, a teoria seniana da justiça fundamenta-se na noção de equidade como "justiça realizável”, que trata desigualmente os desiguais. Seu pressuposto consiste no reconhecimento de que as pessoas, embora sejam iguais perante a lei, possuem necessidades, capacidades e desejos diferenciados. A promoção da equidade na justiça, segundo ele, é o caminho a ser trilhado para a mitigação das desigualdades socioeconômicas intrínsecas a uma sociedade complexa, assim como para a universalização de suas liberdades democráticas. Daí sua defesa da via de mão dupla entre a liberdade e os direitos humanos (tidos como "pretensões éticas constitutivamente associadas à importância da liberdade humana”) (SEN, 2009, p. 401). Disso deriva a mensagem central de sua teoria da justiça, que é o forte nexo de convergência entre igualdade e liberdade e a crítica implícita e explícita às desigualdades com ou sem liberdades (SEN, 2009).

O pensador indiano propõe uma ideia da justiça calcada na base informacional relativa às liberades dos cidadãos, sensível às consequências. Ignorálas, como as liberades que as pessoas de fato conseguem exercer, impede uma base adequada para um sistema de avaliação (SEN, 1999, 2009). Ele adverte que a justiça não pode ser confinada a uma análise interessada apenas nos "resultados de culminação", pois "a sensibilidade às consequências não exige insensibilidade em relação à agência e às relações pessoais na avaliação do que está acontecendo no mundo" (SEN, 2009, p. 255).

Deve-se considerar que a abordagem das capacitações e a ideia de justiça são pluralistas e que pretendem uma "agregação" positiva de componentes heterogêneos, com diferentes funcionamentos. Mas como selecionar valores sociais: indaga Sen. Para alcançar uma escala "acordada" para a avaliação social, deve haver uma espécie de consenso social. Esse é um processo de "escolha social" que demanda debate público e democrático, esclarecimento e averiguação crítica ("imparcialidade aberta"). Ele reconhece que o exercício da escolha democrática de acordo ou consenso pode ser extremamente complexo, uma vez que a escala de valores é uma questão de valoração e julgamento, não de qualquer tecnologia impessoal. Conforme Sen (2009, p. 358), "não há fórmula mágica”.

É mister objetivar diretamente as liberades concretas, que tem amplitude e sensibilidade que lhe permitem um alcance muito maior, pois as liberades das pessoas podem ser estimadas via referência explícita aos rendimentos e aos processos que elas têm motivos para buscar e valorizar. Sen advoga a capacidade de orientar decisões políticas capazes de ampliar a justiça social, especialmente no que toca à minimização das injustiças intoleráveis. Ele se concentra no estabelecimento de critérios capazes de orientar as escolhas no sentido de que elas sejam mais justas que as alternativas viáveis, o que exige transcendência das individualidades (SEN, 1999, 2005, 2009).

O mais importante é que as relações derivadas do ato sejam justas (ainda que parcialmente), evitando-se a injustiça, que é a situação de anomia em que abrem-se brechas para abusos. Uma das ideias relevantes ligadas a essa perspectiva é a de que, embora haja grande variedade de noções sobre o que é justo, há certo consenso em cada momento histórico sobre o fato de certas situações constituírem-se em injustiça intolerável (SEN, 2005, 2009). 
É sugerida uma reflexão que instigue o engajamento efetivo das pessoas não apenas no cumprimento das leis, mas na transformação da sociedade para que ela exclua as injustiças sentidas como inaceitáveis. Para Sen (2009, p. 409), "não se deve confundir obrigação vagamente especificada com ausência de qualquer obrigação". É um equívoco assumir que "já que não é possível resolver todas as disputas através do exame crítico, então não teríamos bases sólidas suficientes para utilizar a ideia de justiça nos casos em que o exame racional leva a um juízo conclusivo" (SEN, 2009, p. 436).

Sen propõe uma teoria capaz de orientar uma escolha valorativa racionalmente informada, baseada na ideia de que "a escolha e a ponderação podem ser difíceis, mas não há nenhuma impossibilidade geral de fazer escolhas arrazoadas baseadas em combinações de objetos diversos" (SEN, 2009, p. 275). A multiplicidade de parâmetros envolvidos impossibilita o desenvolvimento do cálculo unificado e do sistema de hierarquização ${ }^{2}$, o que não impede que não possam ser articulados de forma racional (SEN, 1977, 1999, 2005, 2009).

Dado o exposto, nas páginas seguintes são abordados alguns dos aspectos mais relevantes do mercado nacional de trabalho contemporâneo, mostrando as relações entre a teoria seniana e o caso empírico do Brasil. Nesse sentido, assume-se que o pensamento de Amartya Kumar Sen pode auxiliar na formulação de iniciativas que mitiguem os problemas existentes no mercado nacional de trabalho, favorecendo a inserção de trabalhadores com habilitações qualificadas no sistema produtivo.

\section{RECONFIGURAÇÃO DO MERCADO NACIONAL DE TRABALHO: A ABERTURA ECONÔMICA, AS REFORMAS DO ESTADO E A DESREGULAMENTAÇÃO DAS RELAÇÕES TRABALHISTAS ENTRE 1990 E 2002}

A justaposição de inflexões de natureza conjuntural e estrutural impediu a economia brasileira de continuar operando nos moldes vigentes entre 1930 e 1980, quando esteve voltada ao crescimento, à industrialização, à modernização e à edificação de vínculos mais duradouros entre empregados e empregadores. As sucessivas crises econômicas dos anos de 1980 desencadearam alterações institucionais importantes, que, por sua vez, afetaram profundamente o mundo do trabalho, precipitando um processo ininterrupto de mudanças nas relações trabalhistas e na conformação do mercado nacional de trabalho. Seus desdobramentos fizeram-se sentir especialmente na década seguinte.

Entre 1990 e 2002, a política econômica no Brasil se caracterizou pela busca de adesão às forças globais de mercado.
2 Para Sen, as ações humanas são resultantes de comportamentos tanto individuais quanto sociais não maximizadores. 
Promoveu a desregulamentação crescente da economia, transferindo boa parte de sua condução ao mercado autorregulado. Seu intento era conter a inflação e retomar o crescimento, de modo que a persistente crise econômica fosse superada.

Em julho de 1994, foi instituído o Real, considerado o mais bem sucedido plano de estabilização da economia brasileira. Seu sucesso esteve ligado à desindexação e à redução significativa dos níveis inflacionários. Apesar de seus resultados efetivos para o controle da inflação, o câmbio sobrevalorizado e os juros altos restringiram o crescimento e aumentaram a vulnerabilidade externa, prejudicando as contas públicas (FRANCO, 1995, 1999).

O PIB teve comportamento oscilante na primeira metade desse decênio, inclusive com variação negativa em 1990 (-4,3\%) e em 1992 (-0,05\%). Entre 1993 e 2002, a taxa média de crescimento econômico foi de 2,31\%, com destaque positivo para o triênio 19931995 e negativo para o biênio 1998-1999. Já a inflação foi galopante até 1994, com média de 1321,28\% a.a., permanecendo como o desafio central das políticas econômicas. Após o Real, a inflação diminuiu de maneira consistente, com média de 9,24\% a.a. entre 1995 e 2002.

Tabela 1. Evolução percentual das taxas médias anuais do PIB e da inflação Brasil (1990-2002)

\begin{tabular}{c|c|c}
\hline Ano & PIB & Inflação (IPCA) \\
\hline 1990 & $-4,3$ & 1620,97 \\
1991 & 1,0 & 472,7 \\
1992 & $-0,05$ & $1.119,10$ \\
1993 & 4,67 & $2.477,15$ \\
1994 & 5,33 & 916,46 \\
1995 & 4,42 & 22,41 \\
1996 & 2,15 & 9,56 \\
1997 & 3,38 & 5,22 \\
1998 & 0,04 & 1,65 \\
1999 & 0,25 & 8,94 \\
2000 & 4,31 & 5,97 \\
2001 & 1,31 & 7,67 \\
2002 & 2,66 & 12,53 \\
\hline
\end{tabular}

Fonte: IBGE/SCN, 2016a; IBGE/SNIPC, 2016. Elaboração própria.

Nesse período, a abertura econômica avançou ${ }^{3}$. Norteados para essa finalidade, segundo Yano e Monteiro (2006), Lacerda et al (2010) e Giambiagi et al (2011), quatro aspectos se sobressaíram em conjunto na economia brasileira. Foram eles:

i) abertura comercial: combinada à redução gradativa das tarifas de importação e à valorização crescente da taxa de câmbio, expôs as atividades produtivas internas à forte concorrência internacional, sem adaptação prévia dos fatores de competitividade sistêmica. Isso favoreceu as importações ao passo que dificultou as exportações;

ii) nova política industrial: redirecionada ao aumento da competitividade e da produtividade, cujo embrião foi o documento
Para a discussão pormenorizada sobre a abertura econômica nos países emergentes, ver Chokski, Michaely e Papageorgiu (1991) e Rodrik (1997). 
nomeado de Diretrizes Gerais para a Política Industrial e de Comércio Exterior - Pice (BRASIL, 1991). Somada à recessão do início da década de 1990, ensejou as empresas a promoverem severos ajustes estendidos pelos anos seguintes, diminuindo a participação do setor industrial na composição do PIB, aumentando significativamente o número de demissões ${ }^{4}$ e acarretando um processo progressivo de desverticalização e terceirização do trabalho;

iii) programa de privatizações: a criação do Programa Nacional de Desestatização - PND (BRASIL, 1992) intensificou o processo de privatizações e o tornou importante na agenda do governo, impactando especialmente os empregos do setor público ${ }^{5}$. Inicialmente, o foco do PND foi a venda de estatais produtivas, de setores até então considerados estratégicos para o desenvolvimento nacional (siderúrgicos, fertilizantes e petroquímicos). Em 1995, o PND foi ampliado, com concessões de serviços públicos à iniciativa privada, mediante obrigações como a melhoria de sua qualidade (eletricidade, transportes e telecomunicações);

iv) abertura financeira: especialmente pós 1990, o Brasil ampliou seu sistema financeiro via diminuição crescente de seus mecanismos de controle, seguindo a tendência mundial da globalização de amoldar-se a um ambiente institucional favorável ao fluxo internacional de capitais. O País estabeleceu dois eixos basilares: flexibilização da entrada de investidores estrangeiros e adaptação do marco regulatório doméstico ao novo modelo de financiamento internacional. Se, por um lado, isso permitiu a modernização de áreas como infraestrutura, tecnologia e registro de patentes, por outro, implicou em crescente vulnerabilidade externa.

Há que se considerar ainda que a introdução das tecnologias da informação e da comunicação - muitas delas poupadoras de mão de obra - fecharam definitivamente numerosos postos de trabalho. Diante desse panorama, vê-se que as políticas econômicas de ajuste estrutural pautaram-se primordialmente pelos princípios da economia de mercado, evidenciando o propósito de alinhar-se rapidamente à nova ordem econômica mundial ${ }^{6}$.

Esse cenário permite traçar um paralelo com a visão seniana de economia e sociedade. Para ele, é fundamental a incorporação da questão da justiça à discussão sobre o desenvolvimento. A teoria econômica convencional - artífice das transformações ocorridas nos anos de 1990 - empobreceu seu próprio approach ao rejeitar uma miríade de considerações que determinam os comportamentos humanos, inclusive os econômicos, e focou tão somente as motivações ditadas pelo autointeresse (SEN, 1977, 2005, 2009).

A razão da existência de qualquer governo é a capacidade de resguardar seus cidadãos da insegurança. Um regime global que tolhe os Estados de implementar essa função protetora cria as condições para instabilidade política, econômica e social aguda. O êxito das finanças globais e a diminuição da possibilidade de disciplinar política
4 Conforme Lacerda et al (2010), a diminuição dos postos de trabalho industriais foi tendência inexorável nos anos noventade 1990 e essas demissões abrangeram áreas operacionais,

administrativas e cargos de direção, denotando um ajuste produtivo e também uma reestruturação dos processos administrativos.

5 Em 1989, começa a demissão de funcionários públicos não estáveis, a limitação de contratações, estímulos à aposentadoria e terceirização de serviços. Na década de 1990, houve o Plano de Demissão Voluntária e a continuidade de políticas restritivas, como o congelamento de vagas. Mas foi o PND que

produziu efeitos mais permanentes (PESSOA e MARTINS, 2003).

${ }^{6}$ A nova ordem econômica mundial surgiu de um conjunto de propostas expressas pelas Nações Unidas, em 1974. Mais tarde, incorporou o chamado Consenso de Washington, resultante de um encontro do Institute for International Economics nos Estados Unidos, em 1989.O objetivo alegado era diminuir a disparidade de poder nas relações econômicas entre países industrializados e em desenvolvimento. Ver Williamson (1989) e Rajagopal (2003). 
e socialmente a economia são as características mais salientes do sistema de mercado. Nesse sentido, a análise de Sen fornece elementos para entender por que o alinhamento do Brasil à desregulamentação global no período redundou em precarização das condições de trabalho.

$\mathrm{Na}$ esteira dos eventos econômicos, a redefinição do papel do Estado e as alterações na legislação trabalhista foram as duas inflexões institucionais que definiram a configuração que o mercado de trabalho desvelou nos anos seguintes. A primeira diz respeito à inauguração de um novo momento na história da administração pública. O discurso de modernização do Estado, circunscrito apenas a algumas áreas da estrutura econômica no início, gradativamente, consolidou-se. O Plano Diretor da Reforma do Aparelho de Estado (BRASIL, 1995) o oficializou, tornando-o objetivo geral. Isso resultou em diminuição do aparato administrativo, ao contrário do previsto pela Constituição da República Federativa do Brasil - $\mathrm{CF} / 88$, originária das organizações sociais derivadas do processo de abertura política (1979-1988) que pressionaram pela participação mais democrática na definição dos rumos do País?.

A questão dos serviços públicos tomou o centro do debate. Propôs-se a redução da estrutura pública, prevendo-se a descentralização de atividades e sua orientação para o mercado. A adoção dessa opção foi interpretada (e justificada) dentro da lógica da eficiência gerencial e da diminuição dos custos, diante da crise do Estado e do contexto internacional. As mudanças implementadas então visavam aumentar a produtividade da economia e, com isso, melhorar a performance da economia brasileira (YANO e MONTEIRO, 2006).

Essencialmente, propôs-se passar de um "Estado-empresário e de bem-estar social" para um "Estado regulador e fiscal". Procurou-se condenar ao nível da racionalidade estritamente econômica o primeiro modelo, o que subsidiou a discussão sobre reformas "inevitáveis" da administração pública. $O$ apelo central do argumento foi privatizar os serviços, amainado pelo incentivo à filantropia social. Em que pese a crise do Estado, a abordagem economicista omitiu contradições resultantes da nova ordem econômica mundial.

Destarte, abordar o processo de redefinição do papel do Estado como derivação mecânica da lógica de incentivar a competição e a eficiência induz à supressão dos aspectos políticoeconômicos implícitos na concorrência imposta à fatia do "mercado" de serviços parcialmente geridos até então pelo Estado. Isso tendo em vista a persistência das dificuldades pelas quais passava a economia brasileira, por um lado, e as conquistas sociais alcançadas a partir da cidadania e a ampliação dos direitos sociais e trabalhistas instituídos na CF/88, por outro.
7 Esses movimentos foram essenciais na transição para a democracia que se institucionalizou na $\mathrm{CF} / 88$, tida como a esperança da implantação de um Estado de bem-estar social. Seus fundamentos são caracterizados pelo(a): i) Estado atuando como regulador, garantindo a segurança econômica; ii) redistribuição equitativa das riquezas produzidas como um fim; iii) Estado agindo como provedor de serviços; iv) política social devendo ter um papel essencial na correção das desigualdades (MÉRRIEN, 1994). 
As ponderações de Sen são oportunas para avaliar os desdobramentos das opções adotadas pelo governo federal no período. O pensador indiano esclarece que o capital social é vital como fator de transformação dos recursos pessoais em bem-estar social, isto é, as relações interpessoais são determinísticas. Para o desenvolvimento socioeconômico, o autor aceita que o autointeresse e os mercados tenham importância no processo, mas são os valores sociais que preponderam para o alcance desse objetivo. As relações sociais e a cidadania (nos seus direitos e deveres) têm relevância maior que mero valor instrumental (SEN, 1999, 2009).

Para Sen, os custos sociais do capitalismo desregulamentado são desconsiderados pelo mecanismo automático de preços, redundando em danos à sociedade em geral, tais como: crises financeiras, perda da identidade cultural e insegurança laboral (SEN, 1997, 1999). Os bloqueios ao acesso às habilitações não são destravados pela desregulamentação do mercado. Por isso, "o Estado e a sociedade têm papéis no fortalecimento e na proteção das capacidades humanas. São papéis de sustentação, e não de entrega sob encomenda" (SEN, 1999, p. 71).

Por exemplo, deve ser de responsabilidade social que a questão do trabalho precário seja superada e que todos os cidadãos tenham a possibilidade real de encontrar um trabalho decente. É também responsabilidade compartilhada pela sociedade que as diferentes políticas públicas se articulem para oferecer "amplas oportunidades de emprego". Mas o autor adverte que, em última análise, a liberdade de como fazer uso dessas oportunidades "é uma responsabilidade do indivíduo" (SEN, 1999, p. 327).

Já as mudanças laborais na seara institucional nessa década foram consonantes à abertura econômica, sintonizadas com os pressupostos do "modelo" de especialização flexível (alternativa ao "modelo" fordista de produção até então em vigor). Grosso modo, pode-se dizer que a regulamentação do mercado de trabalho foi flexibilizada. 


\section{Quadro 1. Mudanças na legislação trabalhista que acompanharam a abertura econômica no Brasil}

\begin{tabular}{|c|c|c|}
\hline $\begin{array}{l}\text { Tipos e componentes } \\
\text { dos contratos }\end{array}$ & $\begin{array}{l}\text { Prévio à abertura econômica (1930 } \\
\text { - fins da década de 1980) }\end{array}$ & $\begin{array}{l}\text { Acompanhando a abertura econômica } \\
\text { (pós 1990) }\end{array}$ \\
\hline Duração & Indeterminada. & $\begin{array}{l}\text { Diferentes arranjos. Contratos por tempo } \\
\text { determinado, parcial, temporário, verbais, } \\
\text { etc. }\end{array}$ \\
\hline Local de trabalho & $\begin{array}{l}\text { Determinado e subordinado } \\
\text { diretamente a um único } \\
\text { empregador/local. }\end{array}$ & $\begin{array}{l}\text { Pode variar de acordo com a realocação } \\
\text { prevista nos contratos de subcontratação } \\
\text { e/ou decisões internas das empresas. }\end{array}$ \\
\hline Jornada & $\begin{array}{l}\text { Determinada, padronizada e em } \\
\text { tempo integral. }\end{array}$ & $\begin{array}{c}\text { Variável, não padronizada. Distribuição } \\
\text { das horas em períodos trimestrais ou } \\
\text { semestrais. }\end{array}$ \\
\hline Horas-extras & $\begin{array}{l}\text { Prática comum. Remuneração } \\
\text { maior imposta pela legislação. }\end{array}$ & $\begin{array}{l}\text { Práticas de compensação de horas } \\
\text { ("banco de horas"). }\end{array}$ \\
\hline Hierarquia & $\begin{array}{l}\text { Definida. Predominância de níveis } \\
\text { verticais. }\end{array}$ & $\begin{array}{c}\text { Definida. Predominância de equipes e } \\
\text { níveis horizontais. }\end{array}$ \\
\hline $\begin{array}{c}\text { Período de } \\
\text { experimentação }\end{array}$ & Curto, restrito a 2 ou 3 meses. & $\begin{array}{c}\text { Ampliado, podendo atingir } 6 \text { meses ou } \\
\text { mais. }\end{array}$ \\
\hline Funções e atividades & Circunscritas. & Polivalentes. \\
\hline $\begin{array}{l}\text { Organização do } \\
\text { trabalho }\end{array}$ & $\begin{array}{l}\text { Hierarquizada, com valorização da } \\
\text { senioridade. }\end{array}$ & Flexível, exigindo capacitação continuada. \\
\hline Salário & Determinado. & Variável, parcial ou totalmente. \\
\hline Aumentos Salariais & $\begin{array}{l}\text { Periódicos, vinculados à } \\
\text { produtividade e indexados aos } \\
\text { índices de preços ao consumidor. }\end{array}$ & $\begin{array}{c}\text { Descontínuos, associados a metas, } \\
\text { resultados, qualidade, adaptabilidade ou } \\
\text { bonificações. }\end{array}$ \\
\hline Estabilidade & Valorizada. & $\begin{array}{c}\text { Valorizada apenas para o núcleo duro dos } \\
\text { trabalhadores. }\end{array}$ \\
\hline $\begin{array}{l}\text { Rescisão de contrato } \\
\text { por parte do } \\
\text { empregador } \\
\end{array}$ & $\begin{array}{l}\text { Restrições e indenizações } \\
\text { impostas pela legislação. }\end{array}$ & $\begin{array}{l}\text { Diminuição e/ou eliminação das restrições } \\
\text { da legislação. }\end{array}$ \\
\hline Negociação coletiva & Centralizada ou por setores. & $\begin{array}{c}\text { Descentralizada, preferencialmente por } \\
\text { empresa. }\end{array}$ \\
\hline Contratos coletivos & $\begin{array}{l}\text { Definição de um contrato } \\
\text { "modelo". }\end{array}$ & $\begin{array}{l}\text { Perda da importância do contrato } \\
\text { "modelo". }\end{array}$ \\
\hline
\end{tabular}

Fonte: Adaptado de Cacciamali (2005, p. 14-15).

Nota: no estudo original, a autora analisa a América Latina ressaltando que, embora com velocidade e com estratégias políticas distintas, seguiu-se o mesmo padrão em todos os países da região.

O quadro 1 atesta que as reformas laborais levadas a cabo pós 1990 pautaram-se pelos preceitos da nova ordem econômica mundial. Esse processo evoluiu de forma descontínua, acumulando resultados consistentes com a proposta de flexibilização do mundo do trabalho. É importante salientar que, excetuando-se as conquistas obtidas mediante acordos ou convenções coletivas desde a CF/88, nesse período, praticamente todas as alterações nos direitos trabalhistas foram no sentido de diminuí-los e/ou de intensificar o ritmo de trabalho.

Caso se avalie a efetividade de cada medida, algumas tiveram maior incidência do que outras. Entretanto, se elas forem analisadas conjuntamente e inseridas no contexto das transformações da economia brasileira, percebe-se que sua influência transcende seus impactos mais diretos. Essas alterações institucionais favoreceram a desregulamentação do trabalho, na contramão do processo de implantação do Estado de bem-estar social. 
A análise proposta por Sen (1999) permite contrapor a maneira como se deu a desregulamentação das relações de trabalho implementada no período. Ele afirma que o "desenvolvimento como liberdade" implica que o alargamento das liberdades substantivas necessita (e geralmente é acompanhada) de ampliação dos direitos trabalhistas que favoreçam os acessos básicos a uma vida digna. Todavia, ao privilegiar-se o sistema de mercado corre-se sério risco de retirar dos menos favorecidos toda e qualquer condição de liberdade considerada essencial para a promoção de uma real condição de desenvolvimento.

Além disso, o autor afirma que "os indivíduos vivem e agem num mundo de instituições" (SEN, 1999, p. 168). Suas oportunidades e projetos dependem de forma crucial das instituições existentes e de seu funcionamento conjunto. Por isso, ele assevera que compartilhar oportunidades requer intervenção pública diligente, evocando como álibi o histórico de intervenção estatal dos países mais avançados economicamente na promoção de seus próprios modelos de desenvolvimento socioeconômico, que implementaram intencionalmente políticas de educação, saúde, seguridade social, emprego e renda. Ademais, Sen é enfático ao assumir que "mesmo quando é suprema a necessidade de uma 'reforma econômica' para dar mais espaço aos mercados, essas facilidades desvinculadas do mercado requerem uma ação pública cuidadosa e resoluta" (SEN, 1999, p. 169).

Todavia, esse não parece ter sido o caso. Devido ao desempenho claudicante da economia brasileira e às inúmeras alterações institucionais nas relações trabalhistas, houve piora no que se refere ao mercado de trabalho. Seus efeitos colaboraram substancialmente no sentido de piorar a situação, vide a deterioração dos seus principais indicadores.

O principal indicador desse cenário foi a tendência de elevação do número de desempregados. A taxa de desemprego - TD no País, que era de 4,6\% em 1990, saltou para 10,4\% em 1999, e encerrou a série em 2002, com 9,9\%, mais de cinco pontos percentuais acima da registrada em 1990. A elevação de patamar da taxa de desemprego fica também evidente nas diferentes áreas de abrangência, apesar da indisponibilidade de dados para 1990 e 1991.

\begin{tabular}{|c|c|c|c|c|c|}
\hline \multicolumn{6}{|c|}{ País (1990-2002) } \\
\hline Ano & TD & $\begin{array}{c}\text { TD (áreas } \\
\text { metropolitanas) }\end{array}$ & $\begin{array}{l}\text { TD (áreas não- } \\
\text { metropolitanas) }\end{array}$ & $\begin{array}{l}\text { TD (áreas } \\
\text { rurais) }\end{array}$ & $\begin{array}{c}\text { TD (áreas urbanas não } \\
\text { metropolitanas) }\end{array}$ \\
\hline 1990 & 4,6 & - & - & - & - \\
\hline 1991 & 7,2 & - & - & - & - \\
\hline 1992 & 7,2 & 9,7 & 6,1 & 1,9 & 8,0 \\
\hline 1993 & 6,8 & 9,5 & 5,6 & 1,8 & 7,3 \\
\hline 1994 & - & - & - & - & - \\
\hline 1995 & 6,7 & 8,3 & 5,9 & 2,0 & 7,6 \\
\hline 1996 & 7,6 & 9,8 & 6,6 & 2,5 & 8,2 \\
\hline 1997 & 8,5 & 11,6 & 7,0 & 2,6 & 8,8 \\
\hline 1998 & 9,7 & 13,6 & 8,0 & 3,3 & 9,8 \\
\hline 1999 & 10,4 & 14,4 & 8,6 & 3,4 & 10,7 \\
\hline 2000 & - & - & - & - & - \\
\hline 2001 & 10,1 & 13,0 & 8,6 & 3,0 & 10,2 \\
\hline 2002 & 9,9 & 13,5 & 8,1 & 2,7 & 9,6 \\
\hline
\end{tabular}

Fonte: IBGE/PNAD, 2016. Elaboração própria.

Notas: (1) Em 1994 e 2000, o IBGE não realizou a PNAD; (2) Nova metodologia de cálculo em 2002. 


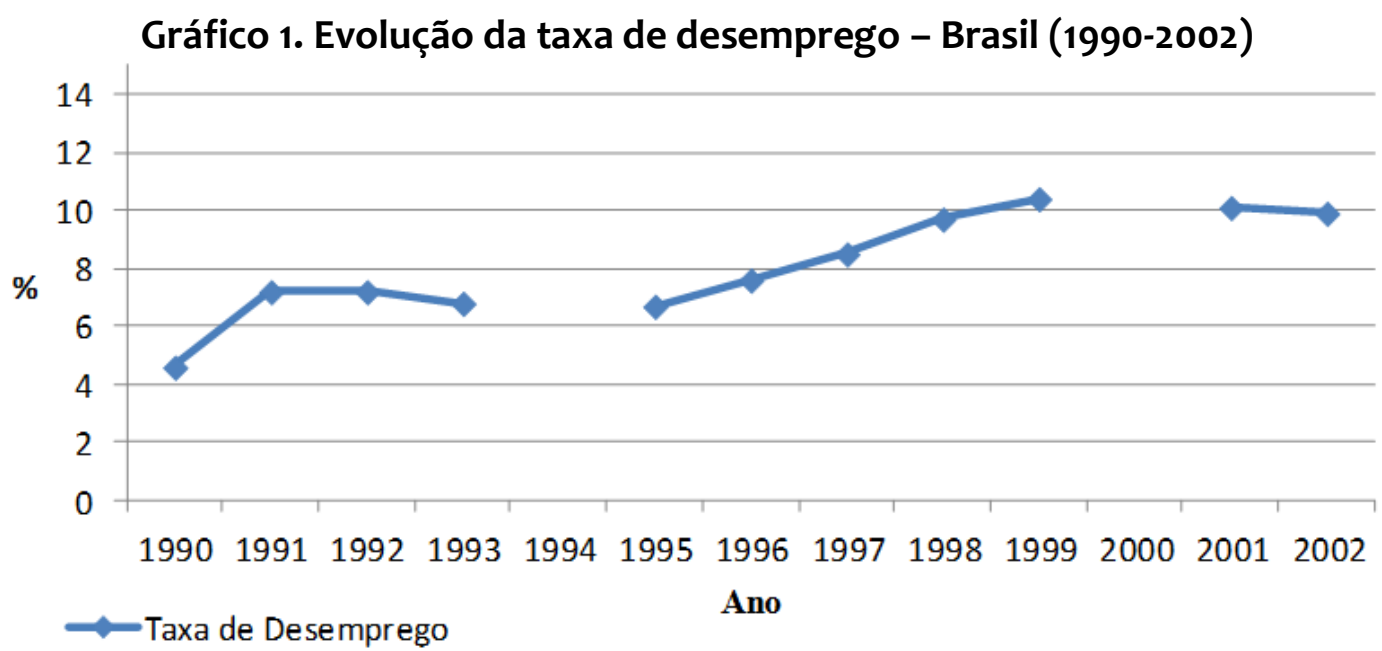

Fonte: IBGE/PNAD, 2016. Elaboração própria.

Esses números mostram o encolhimento relativo do mercado de trabalho regulamentado pela legislação trabalhista e integrado aos mecanismos institucionais garantidores da proteção ao trabalho. Para Baltar (2003), a ampliação do desemprego indicou uma transformação intensa no mundo do trabalho, em decorrência da instabilidade e da falta de expectativas de melhora da atividade econômica. Estas modificações foram estimuladas por reformas voltadas ao sistema de mercado e pela redefinição do papel do Estado, somadas às alegadas necessidades de adaptação dos contratos de trabalho à nova (des)regulamentação.

Ressalta-se que as transformações no mundo do trabalho entre 1990 e 2002 foram de retrocesso dos direitos trabalhistas. A nova ordem econômica mundial piorou as condições do mercado nacional de trabalho. A baixa capacidade de geração de emprego em um cenário de restrita regulamentação social induziu que tal problema se manifestasse, sobretudo, pela proliferação de ocupações de baixo rendimento e qualificação profissional (DEDECCA, 2005).

A questão da qualificação profissional no Brasil merece reflexão. Negligenciada que foi através dos tempos, a baixa qualificação da mão de obra brasileira configura-se apenas como o sinal mais aparente - e um dos mais importantes na ótica do sistema de mercado - da pouca efetividade do sistema educacional do País. Esse é um desafio fulcral a ser equalizado para que seja viável uma trajetória de crescimento econômico sustentado. Mais do que isso, é do desenvolvimento social resultante de um sistema educacional universal - de qualidade e para a vida toda - que poderá derivar o almejado crescimento. Como elemento estratégico na indução do desenvolvimento socioeconômico, é papel fundamental do Estado fomentá-lo e garanti-lo institucionalmente em todas as esferas de ensino. Isso deve significar transitar cada vez mais da formação para o mundo trabalho, enquanto condição de financiamento da sobrevivência, para a posição de desenvolvimento humano integral. 
Sen (1999, 2005), analisando especificamente os efeitos educacionais, aponta que o acesso à educação de qualidade reforça o poder de decisão de uma pessoa para toda a vida. Isso de várias maneiras, tais como: maior autonomia e status social, melhor conhecimento do mundo a sua volta e maior aptidão para influenciar positivamente as decisões de outrem. Essa é uma liberdade instrumental que promove liberdades substantivas no plano social e individual, que, por sua vez, reforçam-se e complementam-se mutuamente.

Ampliam-se assim tanto as iniciativas individuais, no sentido de superar as adversidades da vida social e pessoal, quanto as oportunidades sociais geradas, sendo a inserção qualificada no mercado de trabalho apenas uma dentre as múltiplas possibilidades de desenvolvimento, denotando a importância da condição de agente. Essa abordagem põe em xeque "a crença tão dominante em muitos círculos de que o 'desenvolvimento humano' [...] é realmente um tipo de luxo que apenas os países mais ricos podem se dar" (SEN, 1999, p. 58).

\section{MERCADO NACIONAL DE TRABALHO RECONFIGURADO: ESTABILIDADE ECONÔMICA, RETOMADA (PARCIAL) DA REGULAÇÃO LABORAL E AVANÇOS SOCIAIS ENTRE 2003 E 2014}

Se o cenário nacional no interregno 1990-2002 foi marcado pela abertura econômica, pela redefinição do papel do Estado e por desregulamentação das relações trabalhistas, o intervalo 2003-2014 se caracterizou pela consolidação da estabilização econômica e da inserção internacional, com avanços sociais expressivos. Na seara institucional, os sinais foram contraditórios, com mudanças voltadas tanto ao aprofundamento da flexibilização quanto à retomada da regulação laboral.

Essa realidade esteve associada ao mercado nacional de trabalho reconfigurado, sujeito às céleres variações na composição das atividades produtivas. A despeito da conjuntura favorável e do ciclo econômico virtuoso que se inaugurou, houve obstáculos para o retorno consistente do crescimento econômico. Isso por conta de problemas sociais e econômicos crônicos ${ }^{8}$, passíveis de impactos significativos no mundo do trabalho (IPEA, 2009).

O desempenho econômico brasileiro a partir de 2003 foi bastante influenciado pelos movimentos da economia internacional e da taxa de câmbio - dada a continuidade do regime de metas de inflação inaugurado em 1999-, com persistente tendência de apreciação do Real. Quanto ao nível de atividade e ao comportamento dos preços, os resultados foram positivos (tabela 3). O PIB, em 2003, apresentou crescimento de apenas 1,15\%. Contudo, acompanhando o significativo crescimento mundial até 2008, a economia brasileira mostrou dinamismo. Apenas em 20090
8 Basta inferir que a desigualdade permaneceu entre as 12 mais altas do mundo (IPEA, 2009). 
crescimento foi interrompido pela crise financeira internacional (ver AKB, 2010), retornando com vigor em 2010 (7,53\%) até praticamente estagnar em 2014 (0,1\%). Entre 2003 e 2008, a taxa média de crescimento do PIB foi de $4,21 \%$, enquanto que, entre 2009 e 2014 , foi de $2,34 \%$.

A inflação entre 2003 e 2014 apresentou taxa média de 5,91\% a.a., mantendose dentro do intervalo de tolerância definido pela política econômica. Esse patamar bem menor em comparação com a taxa média anual de inflação observada no período 1990-2002 corroborou para a consolidação do processo de estabilização econômica e fomentou o otimismo com a evolução futura da economia brasileira.

Tabela 3 - Evolução percentual das taxas médias anuais do PIB e da inflação
\begin{tabular}{c|c|c}
\multicolumn{3}{|c}{ Brasil (2003-2014) } \\
\hline Ano & PIB & Inflação (IPCA) \\
\hline 2003 & 1,15 & 9,3 \\
2004 & 5,71 & 7,6 \\
2005 & 3,16 & 5,69 \\
2006 & 3,96 & 3,14 \\
2007 & 6,09 & 4,46 \\
2008 & 5,17 & 5,9 \\
2009 & $-0,33$ & 4,31 \\
2010 & 7,53 & 5,91 \\
2011 & 2,73 & 6,5 \\
2012 & 1,03 & 5,84 \\
2013 & 3,0 & 5,91 \\
2014 & 0,1 & 6,41 \\
\hline
\end{tabular}

Fonte: IBGE/SCN, 2016a; IBGE/SNIPC, 2016. Elaboração própria.

Quanto à composição do PIB no período (tabela 4), a agricultura atingiu o pico de participação com 7,39\% em 2003, com viés de queda a partir de então, até chegar a 5,71\% em 2013. A indústria de transformação diminuiu significativamente sua participação, atingindo 13,13\% em 2013, o que fomenta um intenso debate sobre o chamado processo de desindustrialização (ver Rowthorn e Ramaswany, 1999; Tregenna, 2009). O setor de serviços apresentou comportamento inverso aos demais enquanto participação no PIB, subindo de 66,33\% em 2002 para 69,32\% em 2013.

Tabela 4. Participação percentual dos setores na composição do PIB (referência 2000) Brasil (2003-2013)

\begin{tabular}{c|c|c|c|c}
\hline Ano & Agropecuária & Indústria & Indústria de transformação & Serviços \\
\hline 2002 & 6,62 & 27,05 & 16,85 & 66,33 \\
2003 & 7,39 & 27,85 & 18,02 & 64,77 \\
2004 & 6,91 & 30,11 & 19,22 & 62,97 \\
2005 & 5,71 & 29,27 & 18,09 & 65,02 \\
2006 & 5,48 & 28,75 & 17,37 & 65,76 \\
2007 & 5,56 & 27,81 & 17,03 & 66,63 \\
2008 & 5,91 & 27,90 & 16,63 & 66,18 \\
2009 & 5,63 & 26,83 & 16,65 & 67,54 \\
2010 & 5,30 & 28,07 & 16,23 & 66,63 \\
2011 & 5,46 & 27,53 & 14,60 & 67,01 \\
2012 & 5,32 & 26,02 & 12,95 & 68,66 \\
2013 & 5,71 & 24,98 & 13,13 & 69,32 \\
\hline
\end{tabular}

Fonte: IBGE/SCN, 2016b. Elaboração própria. 
Não obstante, em 2014 o País continuava com entraves econômicos, como taxas de investimento insuficientes e baixa poupança doméstica. Esses fatores estiveram na base do ressurgimento do problema dos deficit em conta-corrente. Embora o Brasil tivesse avançado na organização das contas públicas, ele teria que se defrontar com alguns desafios similares aos que existiram 20 anos antes (GIAMBIAGGl et al, 2011).

Já os avanços sociais do período decorreram da continuidade do regime de política econômica em curso desde os anos de 1990, acompanhado pela opção de implementar programas sociais abrangentes (FONSECA, CUNHA e BICHARA, 2013). Retomou-se uma maior regulação e participação do Estado, especialmente na questão social. Um exemplo é o Programa Bolsa Família, instituído em 2004 e que atendeu a quase 14 milhões de famílias em 2013. Esse programa de transferência direta aos indivíduos visa beneficiar famílias em situação de (extrema) pobreza em todo o País, com foco não só na garantia de renda, mas também na inclusão produtiva e no acesso aos serviços públicos (BRASIL, 2016).

No que tange à questão da pobreza, Sen avalia que fatores institucionais dessa ordem são importantes por oportunizar as pessoas a enfrentar a vida com liberdade (SEN, 1999, 2009). A pobreza, para Sen (1999, p. 109),

\begin{abstract}
deve ser vista como privação de capacidades básicas em vez de meramente como baixo nível de renda, que é o critério tradicional de identificação da pobreza. A perspectiva da pobreza como privação de capacidades não envolve nenhuma negação da ideia sensata de que a renda baixa é claramente uma das causas principais da pobreza, pois a falta de renda pode ser uma razão primordial da privação de capacidades de uma pessoa [e de um país].
\end{abstract}

Para o pensador indiano, esse tipo de restrição às capacidades básicas dificulta a realização de renda e sua conversão em funcionamentos socialmente adequados. A importância dessa concepção está em que aponta para a necessidade de mudar o foco do crescimento para o desenvolvimento, passando dos meios (distribuição de recursos) para os fins (alcance de realizações ou funcionamentos) que os cidadãos valorizem.

Frisa-se que, diante das circunstâncias internas e do estágio avançado da globalização ainda em pleno curso, não poderia e nem era o caso de reverter totalmente os resultados dos anos de políticas econômicas intensamente prósistema de mercado. Ao mesmo tempo, a maioria dos cidadãos brasileiros acenou democraticamente - via eleições gerais - com o desejo de maior proteção do Estado e de voz ativa para a sociedade civil, buscando retomar e avançar na instituição de um Estado de bem-estar social, conforme prevê o core da CF/88. Assim, buscou-se rumar a um Estado regulador e de bem-estar social.

Quanto à regulação laboral, o interregno 2003-2014 foi ambíguo. Houve medidas que aprofundaram a tese da flexibilização e outras que reforçaram o rumo da regulação do trabalho. No primeiro caso, a agenda ampliou-se como nos casos do aumento da jornada de trabalho, da elevação da taxa de rotatividade, da expansão da contratação atípica e da prática da remuneração variável. Esse movimento não se deu de forma genérica, mas focado em públicos específicos (sobretudo pessoas jurídicas, jovens, micro e pequenas empresas) e foi 
implementado por meio de alterações institucionais pontuais das relações de trabalho.

Essa realidade resultou grandemente da lógica de maior inserção internacional do País na globalização, inibindo a regulação pública e fortalecendo soluções autônomas, com aumento do poder discricionário dos empregadores em determinar as condições de uso e remuneração do trabalho. A flexibilização avançou com a terceirização, a subcontratação e a permanência de alta ilegalidade (BALTAR et al, 2010).

Dentre as principais medidas flexibilizadoras das relações de trabalho no Brasil entre 2003 e 2014, de acordo Krein, Santos e Nunes (2011), merecem destaque ${ }^{9}$ :

i) Reforma previdenciária (2003): extinguiu o regime de previdência pública para os servidores admitidos após a emenda constitucional. Fixou limite para aposentadorias e determinou a instituição dos fundos de pensão. Taxou os inativos, aumentou o limite de idade e impôs mais condições para o servidor alcançar a aposentadoria;

ii) Nova lei de falências (2005): os salários e indenizações devidos aos trabalhadores deixam de serem créditos privilegiados em caso de falência, tendo os empregados de discutir a forma de pagamento com os demais credores em assembleia geral. Além disso, a empresa arrematante é desobrigada a permanecer com os empregados e a pagar a dívida trabalhista;

iii) Super simples (2006): as micro e pequenas empresas continuaram dispensadas de fixar quadro de trabalho em suas dependências, anotar as férias dos empregados no livro ou ficha de registros, comunicar à entidade fiscalizadora quanto à concessão de férias coletivas, etc. Perante a Justiça do Trabalho, o empregador pode fazer-se substituir por representante legal;

iv) Trabalho dos comerciários aos domingos (2007): ratificada, desde que se observe a convenção coletiva e a legislação municipal;

v) Contrato de curto prazo para trabalhador rural (2008): autoriza sua contratação sem registro na Carteira de Trabalho, para serviços de até dois meses. Os direitos trabalhistas são pagos diretamente ao trabalhador, mediante remuneração acordada.

Dentre essas medidas, sobressai-se a reforma previdenciária. Encaminhada e aprovada sob a condução do governo federal, contou com o empenho decisivo dos recursos políticos e institucionais disponíveis. Aprofundou-se a posição adotada pelo governo anterior. Essa perda de direitos influenciou crucialmente na leitura dos agentes econômicos quanto à atuação do governo na questão trabalhista, principalmente no âmbito do Fórum Nacional do Trabalho (ver BRASIL, 2005; Dal Molin, 2012). Já no caso da retomada da regulação pública das relações trabalhistas, segundo Krein, Santos e Nunes (2011), salientam-se:
9 Apesar de não fazer parte do escopo desta pesquisa (que abrange especificamente o período 1990-2014), é importante mencionar a reforma trabalhista

instrumentalizada pela Lei № 13.467 (BRASIL, 2017a) e pela Medida Provisória 808 (BRASIL, 2017b) e que tem, desde então, flexibilizado

significativamente as relações de trabalho no Brasil. Dentre as inúmeras alterações por elas promovidas na

Consolidação das Leis do Trabalho (BRASIL/CLT, 1943), especial destaque para a questão do suporte jurídico anteriormente dado aos trabalhadores e que muda sua concepção, passando a ser "pago" pelo trabalhador em caso de perda de causa ajuizada contra o empregador. 
i) Política de salário mínimo (2005): reajustado de acordo com a inflação do ano anterior e acrescido de aumento real correspondente à variação do PIB dos dois anos anteriores;

ii) Nova regulamentação do estágio (2008): criam-se algumas regras para a sua adoção, tais como o limite de jornada de seis horas diárias e o pagamento de férias;

iii) Estímulo para inclusão do autônomo na seguridade social (2009): reduziu o valor da contribuição previdenciária do autônomo e do microempreendedor individual;

iv) Alteração das regras para o exercício do trabalho doméstico (2014): obrigatoriedade de pagar adicional noturno e exercer controle por ponto, recolhimento do FGTS e mudança do cálculo para os depósitos da Previdência Social (INSS), que caiu de $12 \%$ para $8 \%$ do salário.

A medida mais abrangente nesse sentido foi a política do salário mínimo, elaborando-se um critério concreto de valorização real dos rendimentos, favorecendo a regulação pública da remuneração, pois se mantido ao longo do tempo - desde que combinado com outros mecanismos - apoia o crescimento dos salários das categorias de trabalhadores menos organizados, ao mesmo tempo em que favorece a negociação das demais categorias.

O salário mínimo cresceu 58\% em termos reais entre 2003 e 2013 (gráfico 2), o que significou acréscimo significativo da massa salarial e do consumo de benssalário. A classe "C", que em 2003 representava 34\% do total da população, passou a representar 54\% em 2011 (NERI, 2012).

Gráfico 2 - Salário mínimo real (R\$̣ constantes de dez. 2008, deflacionados pelo INPC) Brasil (2000-2014)

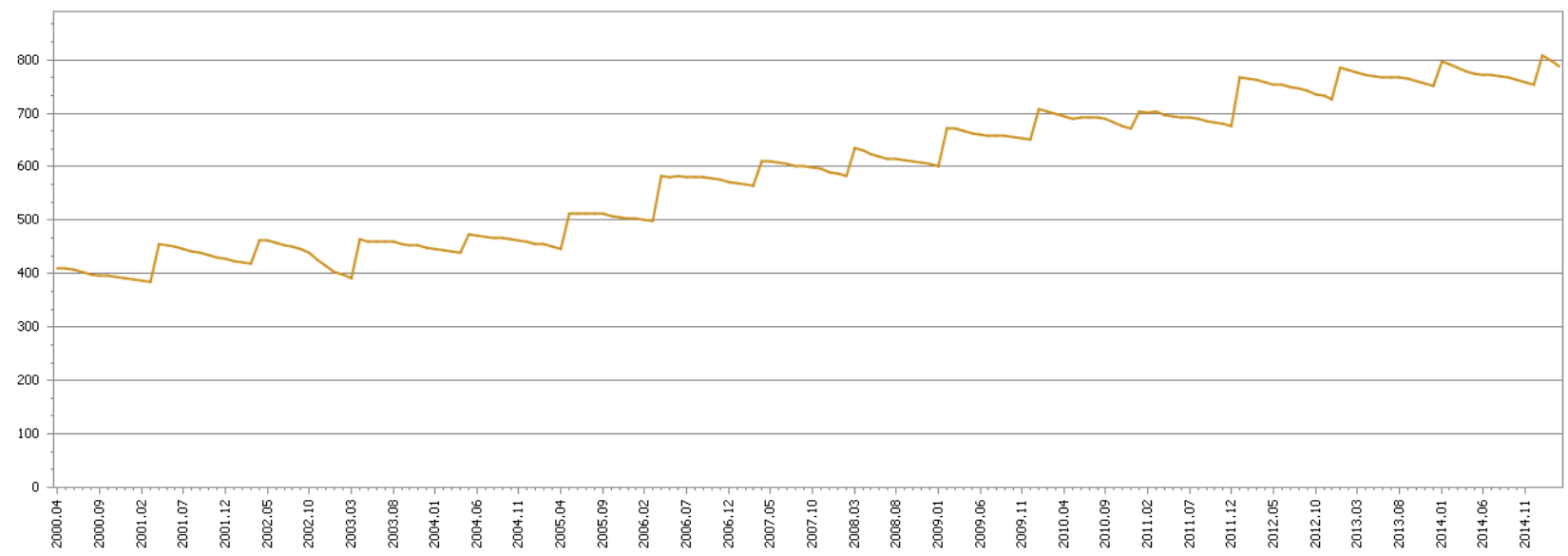

Fonte: IPEADATA, 2016.

A teoria de Sen é útil para a análise da questão dos rendimentos reais na década de 2000, de duas maneiras: i) há inter-relações estreitas entre capacidades, habilitações e rendimentos, mas que não raro recebem ponderação nula na avaliação dos rendimentos reais; ii) à luz da justiça social, mais do que abordar o rendimento insuficiente como forte condição que predispõe à vida empobrecida (o que é absolutamente verdadeiro), há inúmeras razões para abordá-lo em função das potencialidades que o envolvem (SEN, 1999, 2009).

Quanto ao primeiro ponto, Sen $(1999,2009)$ expõe que a maior dificuldade na análise dos rendimentos está na diversidade das funções de demanda das pessoas. Diferenças de idade, gênero, educação formal, condições de saúde e outras podem fazer com que duas pessoas tenham oportunidades ou qualidade de 
vida muito divergentes, mesmo com rendimentos idênticos. O autor sugere avaliar os rendimentos com base na capacidade de gerar combinações funcionais valorativas, que podem ser julgadas de modo comparativo, indo além de avaliações fundadas nas "realizações" e recursos disponíveis, que não consideram o fato deles serem intrinsecamente valiosos por decorrem do exercício da liberdade.

O segundo ponto corresponde ao argumento de que o aumento dos rendimentos per se não deve ser a finalidade da política pública. Questões mais essenciais devem impelir o Estado e a sociedade civil a encará-lo como favorecedor de liberdades instrumentais, compreendendo a questão dos rendimentos em termos da expansão das liberdades substantivas. Assim, o desemprego e o trabalho precário evidenciam o contraste entre a perspectiva do rendimento e das potencialidades (SEN, 1999).

Há provas abundantes de que o desemprego [e o trabalho precário] têm efeitos abrangentes além da perda de renda, como dano psicológico, perda de motivação para o trabalho, perda de habilidade e autoconfiança, aumento de doenças de morbidez [...], perturbação das relações familiares e da vida social, intensificação da exclusão social e acentuação de tensões raciais e das assimetrias entre os sexos. (SEN, 1999, p. 117).

Note-se que os sinais desse período foram contraditórios. O ambiente econômico favorável contribuiu para diminuir a pressão por flexibilização do trabalho. As medidas pontuais oscilaram entre a flexibilização e a ampliação da regulação pública. Excetuando-se a política de salário mínimo no segundo caso, não houve alterações de maior impacto.

Já o desempenho do mercado nacional de trabalho foi positivo entre $2003 \mathrm{e}$ 2014, com melhora de seus principais indicadores, como no caso das taxas de desemprego. Também é verdade que ele se fragmentou, heterogeneizou-se e complexificou-se em relação ao período anterior, com que, na atualidade, tem-se um mundo do trabalho reconfigurado.

O otimismo com a evolução econômica do País intensificou a demanda por trabalho, resultando em queda das taxas de desemprego, de 10,5\% em 2003 para $6,7 \%$ em 2012. No biênio seguinte, subiu, atingindo $7,5 \%$. As áreas metropolitanas em 2014 registraram 8,4\%, quase seis pontos percentuais abaixo das registradas em 2003 (14,1\%). Observa-se ainda que elas se elevaram nas áreas rurais, passando de 2,7\% em 2003 para 4,9\% em 2014, atribuída mormente ao aumento do agronegócio (ver Brum e Muller, 2009; BRASIL, 2010). 
Tabela 5. Taxa de desemprego (\%) - Brasil e diferentes áreas de abrangência (2003-2014)

\begin{tabular}{c|c|c|c|c|c}
\hline Ano & TD & $\begin{array}{c}\text { TD (áreas } \\
\text { metropolitanas) }\end{array}$ & $\begin{array}{c}\text { TD (áreas não- } \\
\text { metropolitanas) }\end{array}$ & $\begin{array}{c}\text { TD (áreas } \\
\text { rurais) }\end{array}$ & $\begin{array}{c}\text { TD (áreas urbanas } \\
\text { não- } \\
\text { metropolitanas) }\end{array}$ \\
\hline 2003 & 10,5 & 14,1 & 8,7 & 2,7 & 10,3 \\
2004 & 9,7 & 13,5 & 7,9 & 3,1 & 9,2 \\
2005 & 10,2 & 13,4 & 8,6 & 3,5 & 10,0 \\
2006 & 9,2 & 12,1 & 7,8 & 3,7 & 8,8 \\
2007 & 8,9 & 11,3 & 7,7 & 3,7 & 8,7 \\
2008 & 7,8 & 9,6 & 6,9 & 3,4 & 7,7 \\
2009 & 9,1 & 10,7 & 8,2 & 4,4 & 9,1 \\
2010 & - & - & - & - & - \\
2011 & 7,3 & 7,9 & 7,0 & 3,8 & 7,6 \\
2012 & 6,7 & 7,4 & 6,4 & 4,6 & 6,8 \\
2013 & 7,1 & 7,8 & 6,8 & 5,3 & 7,1 \\
2014 & 7,5 & 8,4 & 7,1 & 4,9 & 7,5 \\
\hline
\end{tabular}

Fonte: IBGE/PNAD, 2016b. Elaboração própria. Nota: a PNAD não foi realizada em 2010.

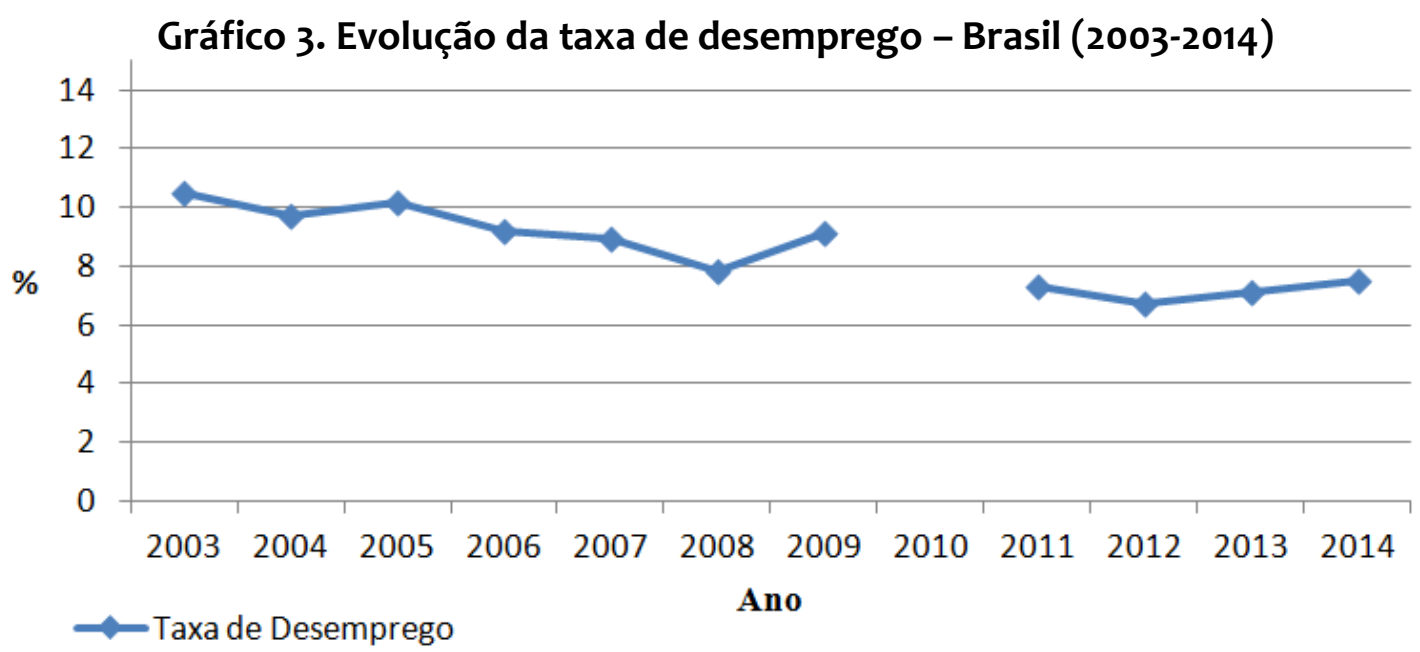

Fonte: IBGE/PNAD, 2016. Elaboração própria.

Um fenômeno importante verificado nesse período foi a crescente rotatividade da mão de obra, entendida como a substituição de um trabalhador por outro no mesmo posto de trabalho. Destaca-se o fato dela ter ocorrido especialmente entre as ocupações de baixa remuneração e qualificação profissional, a despeito de se estar demandando mão de obra mais escolarizada (DIAS e SANSON, 2014; IBARRA, 2013). 


\section{Gráfico 4. Taxa de rotatividade no mercado celetista (\%) - Brasil (2003-2013)}

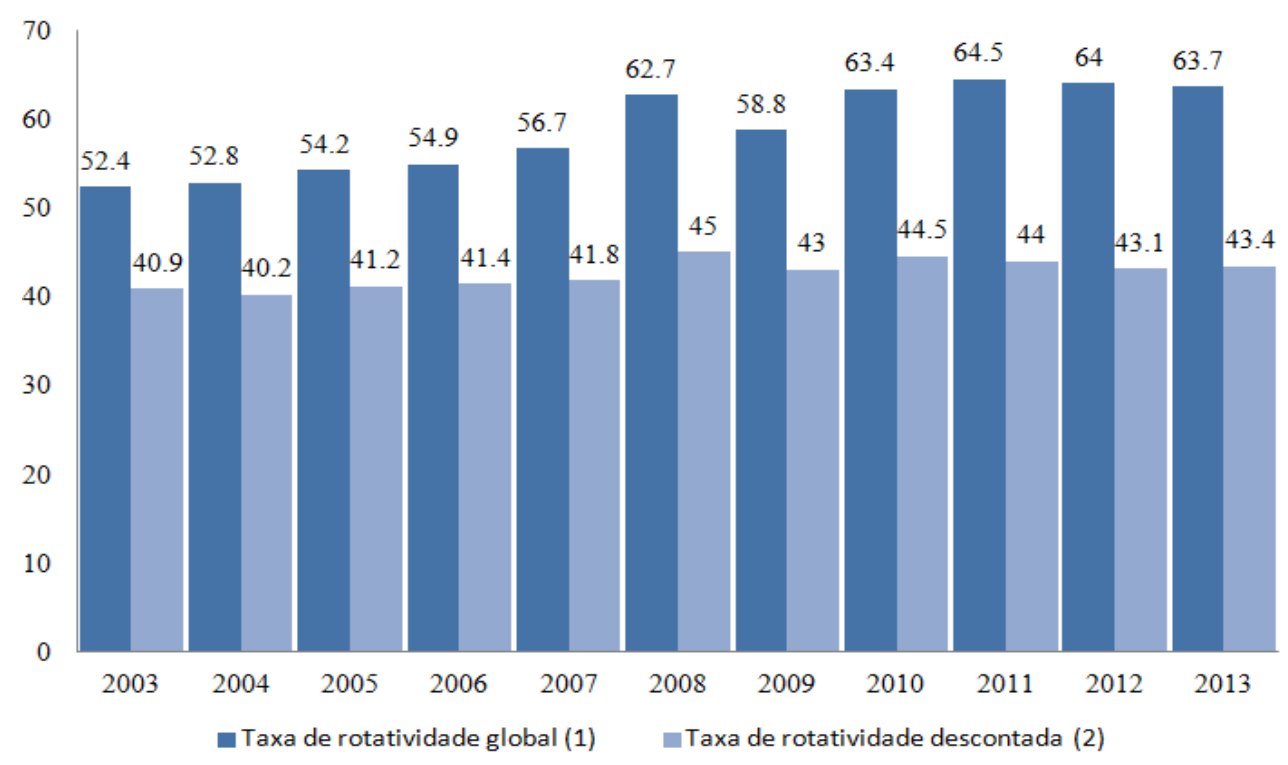

Fonte: MTE/RAIS (2015). Elaboração própria.

Notas: (1) Considera todos os motivos de desligamentos. (2) Exclui os desligamentos motivados por transferência, aposentadoria, falecimento e demissão voluntária.

O aumento da rotatividade ocorreu especialmente em função do desligamento a pedido do empregado que, via de regra, procurou novos empregos almejando aumentos salariais. É verdade também que esse movimento deixou um contingente maior de trabalhadores mais suscetíveis a serem dispensados. Outro ponto é que o "aumento da taxa de rotatividade global ocorreu concomitantemente à redução na taxa de desocupação no país", salvo em 2010, quando se elevou dada à crise econômica iniciada no ano anterior (IBARRA, 2013, p. 254).

Também impactou o mercado nacional de trabalho no período a celebração expressiva de "contratos atípicos de trabalho". Isso, em tese, alcança, inter alia, a rede de proteção do trabalhador, como o "princípio da continuidade do trabalho", impingindo-o a ocupações precárias e instáveis. É o contrário do acordo estável e duradouro estabelecido entre empregado e empregador, que favorece sua permanência por um prazo maior e possibilita a "concretização da carreira e a ascensão profissional" (DIAS e SANSON, 2014, p. 180).

Esse é um desafio institucional importante, pois há tendência de aumento dessa prática, deixando paulatinamente os vínculos de trabalho mais frágeis. Isso reduz a influência normativa do regramento jurídico. Atualmente, as relações atípicas de trabalho estão (ainda) sob responsabilidade dos princípios norteadores do desenvolvimento da disciplina jurídica, mas pouco a pouco se tenta escapar à sua incidência. A rigor, as modalidades atípicas de trabalho podem se expandir para a totalidade dos setores econômicos, contaminando, inclusive, núcleos outrora estáveis de trabalhadores (DIAS e SANSON, 2014).

Diante desse cenário, verifica-se que, de modo geral - e em comparação com o período anterior -, ocorreram avanços importantes no mercado nacional de trabalho no século XXI, especialmente a diminuição da taxa de desemprego e a 
valorização do salário mínimo. Todavia, as celebrações dessa retomada por parte do poder público ocultam a existência de um enorme deficit histórico nos números da inserção econômica e social. Há correlação positiva entre a solidez do crescimento econômico e a melhora dos indicadores do mundo do trabalho. Mas esse crescimento não guardou a forte correlação positiva com as garantias dos direitos trabalhistas que registrava antes da década de 1990.

Observa-se, porém, que as formas precárias de inserção no mercado de trabalho "não constituem propriamente uma novidade na história brasileira". A questão da vulnerabilidade tornou-se elemento cada vez mais presente, tanto para quem está no mercado de trabalho quanto para quem está excluído dele. $\mathrm{Na}$ realidade brasileira, essa vulnerabilidade tem sido vivenciada de forma "paradoxal". Se, de um lado, nunca foi alcançada a generalização da condição salarial, de outro, a ausência dela é o fator de maior vulnerabilidade e insegurança (CONSERVA e ARAÚJO, 2008, p. 87-88).

Dito isso, pode-se inferir que os avanços socioeconômicos do Brasil no século XXI foram insuficientes para sanar os problemas do mercado nacional de trabalho. Ainda assim, reconhece-se que o País combinou crescimento econômico com distribuição de renda, favorecendo a mobilidade social por meio da ampliação do emprego, sobretudo para os cidadãos que figuram na base da pirâmide social. Esse ganho conjuntural, porém, em parte desvanece-se quando observado o acirramento do processo de precarização do trabalho por meio da intensificação de fenômenos como a alta rotatividade e a celebração de contratos atípicos de trabalho, que torna os trabalhadores vulneráveis, com o que alijados de um trabalho decente e, por conseguinte, de uma vida digna.

Por fim, cabe destacar que é possível compatibilizar a abordagem das capacitações e a ideia de justiça seniana com a análise da evolução do mercado nacional de trabalho contemporâneo, principalmente via ênfase da consideração da participação do Estado, da sociedade civil e de cada cidadão nos desígnios da nação. A interpretação de Sen denota que o trabalho compõe um engendramento social amplo, condicionado de maneira assaz distinta do verificado pela prescrição do sistema de mercado. Assim, a organização dos homens para produzir modifica-se ao longo do tempo e, tanto sua articulação quanto os conteúdos específicos dos diferentes trabalhos, assumem novas propriedades (SEN, 1999, 2007).

Por isso, o autor alerta para os riscos em tentar extirpar a sociedade do processo decisório: "o desenvolvimento econômico, do modo como o conhecemos [voltado ao crescimento do PIB], pode, na realidade, ser danoso a um país" (SEN, 1999, p.47). Destaca ainda que a racionalidade econômica do homo economicus está próxima de ser uma imbecilidade social (social moron) (SEN, 1977, p. 336) e salienta que contemporaneamente tendemos a encarar a economia como esfera autônoma face à vida social, enfatizando o mercado fundamentalmente como um mecanismo de formação de preços (SEN, 1999, 2005).

O autor sugere como possível alternativa ao mercado autorregulado a consideração, para além dos aspectos econômicos e jurídicos, do arcabouço cultural, histórico, comportamental e dos hábitos sociais que os condicionam e os orientam. Isso porque são esses os eixos que indubitavelmente norteiam o processo de desenvolvimento individual e social. Isso se dará à medida que forem expandidas as liberdades instrumentais e substantivas, tendo como "efeito 
colateral” altamente desejável o desenvolvimento socioeconômico.

\section{CONSIDERAÇÕES FINAIS}

O artigo examinou pontos de convergência e de divergência entre a evolução do mercado nacional de trabalho pós 1990 e alguns aspectos socioeconômicos e institucionais contemporâneos. A abordagem das capacitações e a ideia de justiça de Amartya Sen, calcada em uma visão multidisciplinar, permitiu criar um instrumental de análise compatível com o estudo proposto.

Da análise empreendida resulta a consideração de que, entre 1990 e 2002, a política econômica no Brasil voltou-se à estabilização interna e à inserção internacional, sob um conjunto de medidas pautadas pela nova ordem econômica mundial, buscando superar os entraves ao crescimento. Promoveu-se uma abertura econômica que impactou a dinâmica institucional, provocando a redefinição do papel do Estado e a reconfiguração do mercado nacional de trabalho, com desregulamentação das relações trabalhistas. Isso redundou em aumento do desemprego e precarização do mundo do trabalho. Logo, os acontecimentos do período divergiram da concepção teórica de Sen a respeito do desenvolvimento socioeconômico e de suas implicações.

Nos anos compreendidos entre 2003 e 2014, consolidou-se o processo de estabilização econômica e de inserção internacional do Brasil, associados a avanços sociais significativos. Institucionalmente, o balanço foi ambíguo, com alterações tanto voltadas ao aprofundamento da desregulamentação quanto à retomada da regulação laboral. Essa dinâmica interagiu com um mercado nacional de trabalho reconfigurado, sujeito às céleres variações na composição das atividades produtivas. A despeito da conjuntura favorável e do ciclo econômico virtuoso que se inauguraram, os avanços do período foram insuficientes para sanar alguns dos problemas crônicos do mundo de trabalho, devido ao histórico de problemas sociais e econômicos. Assim, afirma-se que, nesse período, houve convergência apenas parcial entre a teoria seniana e a evolução do mercado nacional de trabalho.

Dado o cenário nacional entre 1990 e 2014, conclui-se que o pensamento de Sen pode auxiliar na formulação de iniciativas que mitiguem os problemas existentes no mercado nacional de trabalho. Seus insights quanto ao funcionamento da economia de mercado - sem negá-la - e de seus efeitos para a vida em sociedade são de grande valia. O mercado resolve apenas as demandas individuais e não os problemas sociais coletivos. Por isso o autor defende que se oportunize a capacitação global dos agentes/cidadãos, com amplas liberdades de escolha e da maneira mais equiparada e justa possível. Escolhas institucionais nesse sentido favorecerão a inserção de trabalhadores com habilitações qualificadas no sistema produtivo.

\section{REFERÊNCIAS}

ASSOCIAÇÃO KEYNESIANA BRASILEIRA. Dossiê da crise II. Porto Alegre: AKB, 2010.

BALTAR, P. E. A. Salários e preços: esboço de uma abordagem teórica. Campinas: Instituto de Economia, UNICAMP, 2003. 
. et al. Moving towards decent work. Labour in the Lula government: reflections on recent Brazilian experience. In: Global Labour University, v. 9, 2010.

BRASIL. Consolidação das Leis do Trabalho (CLT). Decreto-lei $n^{\circ} 5.452$, de $1^{\circ}$ de maio de 1943. Coletânea de Legislação. São Paulo: Atlas, $104^{\circ}$ ed., 2000.

BRASIL. Ministério da Economia, Fazenda e Planejamento. Política industrial e de comércio exterior: diretrizes gerais. Brasília: BRASIL, 1991.

- Ministério da Administração Federal e Reforma do Estado (MARE). Plano Diretor da Reforma do Aparelho do Estado. Brasília: BRASIL, 1995.

Ministério do Desenvolvimento, Indústria e Comércio Exterior. Banco Nacional de Desenvolvimento (BNDES). Privatização no Brasil: 1990-1994, 19952002. Brasília: BRASIL, 2002. Disponível em <http://www.bndes.gov.br/SiteBNDES/export/sites/default/ bndes_pt/Galerias/Arquivos/conhecimento/pnd/Priv_Gov.PDF>. Acesso em: 23 abr. 2016.

- Ministério do Trabalho e do Emprego. Fórum Nacional do Trabalho. Reforma Sindical - PEC 369, Anteprojeto de lei. Brasília: BRASIL, 2005.

- Ministério do Desenvolvimento Agrário (MDA). Um Novo Brasil Rural. Brasília: BRASIL, 2010.

Ministério do Desenvolvimento, Indústria e Comércio Exterior (MDIC). Brasília: BRASIL, 2015. Disponível em <http://www.desenvolvimento.gov. br/portalmdic/arquivos/dwnl_1407264386.pdf>. Acesso em: 22 abr. 2016.

- Ministério do Desenvolvimento Social (MDS). Bolsa Família. Brasília: BRASIL, 2016. Disponível em <http://www.mds.gov.br/bolsafamilia>. Acesso em: 20 abr. 2016.

. Taxa de rotatividade global e descontada (\%) - Brasil (2002-2013). Brasília: MTE/RAIS, 2015. Disponível em: <http://portal.mte.gov.br/rais/>. Acesso em: 20 abr. 2016.

. LEI N 13.467, DE 13 DE JULHO DE 2017. Altera a Consolidação das Leis do Trabalho (CLT), aprovada pelo Decreto-Lei no 5.452, de 10 de maio de 1943, e as Leis nos 6.019, de 3 de janeiro de 1974, 8.036, de 11 de maio de 1990, e 8.212, de 24 de julho de 1991, a fim de adequar a legislação às novas relações de trabalho. Brasília: BRASIL, 2017a.

MEDIDA PROVISÓRIA Nº 808, DE 14 DE NOVEMBRO DE 2017. Altera a Consolidação das Leis do Trabalho - CLT, aprovada pelo Decreto-Lei $n^{\circ} 5.452$, de $1^{\circ}$ de maio de 1943. Brasília: BRASIL, $2017 a$. 
BRUM, A. L; MULLER, P. K. Aspectos do Agronegócio no Brasil. ljuí: Unijui, 2009.

CACCIAMALI, M. C. Política social e reforma laboral no Brasil: os desafios dos sindicatos sob o governo Lula. Revista de Relaciones Laborales, Montevideo, v. 7, p. 64-82, 2005.

CHOKSKI, A.; MICHAELY, M.; PAPAGEORGIU, D. Liberalizing foreign trade. Oxford: $B$. Blackwell, 1991.

CONSERVA, M. S.; ARAÚJO, A. J. S. Informalidade e precarização nos mundos do trabalho. Teor. Pol. e Soc., v.1, n.1, p.75-91, dez. 2008.

DAL MOLIN, N. O Fórum Nacional do Trabalho e as Centrais Sindicais Brasileiras. Revista Latino-Americana de História, v. 1, n. 3, mar. 2012.

DEDECCA, C. S. Notas sobre a evolução do mercado de trabalho no Brasil. Revista de Economia Política, v. 25, n. 1 (97), p. 94-111, jan./mar. 2005.

DIAS, A. P.; SANSON, C. A atual estrutura ocupacional e o papel dos sindicatos no Brasil: análise do século XXI. Revista de Ciências Sociais, n. 41, p. 175-188, out. 2014.

FONSECA. P. C. D.; CUNHA, A. M.; BICHARA, J. S. O Brasil na Era Lula: retorno ao desenvolvimentismo? Nova Economia, v. 23, n. 2, p. 403-428, mai.-ago. 2013.

FRANCO, G. H. B. O desafio brasileiro. São Paulo: Editora 34, 1999.

. O Plano Real e outros ensaios. Rio de Janeiro: Francisco Alves, 1995.

GIAMBIAGI, F.; VILLELA, A.; BARROS DE CASTRO, L; HERMANN, J. Economia brasileira contemporânea: 1945-2010. Rio de Janeiro: Elsevier, 2ed., 2011.

IBARRA, A. Mercado de trabalho brasileiro: identificação dos problemas e propostas de enfrentamento na perspectiva da agenda social-desenvolvimentista. In: Políticas sociais, desenvolvimento e cidadania: economia, distribuição da renda e mercado de trabalho. FONSECA, A.; FAGNANI, E. (Orgs.). São Paulo: Perseu Abramo, 2013.

INSTITUTO BRASILEIRO DE GEOGRAFIA E ESTATÍSTICA, PESQUISA NACIONAL POR AMOSTRA DE DOMICÍLIOS (IBGE/PNAD). Taxa de Desemprego. Brasília: IBGE/PNAD, 2015b. Disponível em: <http://www.ibge.gov.br>. Acesso em: 18 abr. 2016.

INSTITUTO BRASILEIRO DE GEOGRAFIA E ESTATÍSTICA, SISTEMA DE CONTAS NACIONAIS (IBGE/SCN). Participação dos setores na composição do PIB referência 2000 (\%) - Brasil (2002-2013). Brasília: IBGE/SCN, 2016a. Disponível em: <http://www.ibge.gov.br>. Acesso em: 21 abr. 2016. 
Produto Interno Bruto (PIB). Brasília: IBGE/SCN, 2014. Disponível em: <http://www.ibge.gov.br>. Acesso em: 10 abr. 2016.

INSTITUTO BRASILEIRO DE GEOGRAFIA E ESTATÍSTICA, SISTEMA NACIONAL DE ÍNDICES DE PREÇOS AO CONSUMIDOR (IBGE/SNIPC). Inflação: Índice Nacional de Preços ao Consumidor Amplo (IPCA). Brasília: IBGE/SNIPC, 2016. Disponível em: <http://www.ibge.gov.br>. Acesso em: 10 abr. 2016.

INSTITUTO DE PESQUISA ECONÔMICA APLICADA (IPEA). Carta de Conjuntura. Brasília: IPEA, jun. 2009.

Salário mínimo real - Brasil (2000-2014). Brasília: IPEADATA, 2016. Disponível em: <http://www.ipeadata.gov.br/>. Acesso em: 22 abr. 2016.

KREIN, J. D.; SANTOS, A. L.; NUNES, B. T. Trabalho no governo Lula: avanços e contradições. Revista ABET, v. X, n. 2, jul./dez. 2011.

LACERDA, A. C.; REGO, M.; MARQUES, R. M.; SERRA, R. A. M. Economia brasileira. São Paulo: Saraiva, 4 ed., 2010.

MÉRRIEN, F. X. O Estado-Providência. Tradução de Sonia Tomazini. (Collection Que Sais - JE?), 1994.

NERI, M. C. De volta ao país do futuro: crise europeia, projeções e a nova classe média. Rio de Janeiro: FGV/CPS, 2012.

PESSOA, E.; MARTINS, M. O emprego público no Brasil, nos anos 90. Ensaios FEE, Porto Alegre, v. 24, n. 1, p. 249-270, 2003.

RAJAGOPAL, B. International Law from below: development, social movements and Third World Resistance. Cambridge, 2003.

RODRIK, D. Has globalization gone too far? Cambridge: Mass. Inst. Intern Econ., 1997.

ROWTHORN, R.; RAMASWAMY, R. Growth, trade and deindustrialization. International Monetary Fund (IMF) Staff Papers, vol. 46, n.1, March, 1999.

SEN, A. K. [1977]. Rational fools: a critique of the behavioral foundations of economic theory. In: SEN, A. K. Choice, welfare and measurement. Boston: Harvard University Press, p. 84-106, 1997.

. Development as freedom. New York: Oxford University Press, 1999.

. Sobre Ética e Economia. São Paulo: Companhia das Letras, 2005.

. The Idea of Justice. Cambridge: Belknap Harvard, 2009. 
TREGENNA, F. Characterizing deindustrialization: an analysis of changes in manufacturing employment and output internationally. Cambridge Journal of Economics, v. 33 (3), p. 433-466, 2009.

WILLIAMSON, J. What Washington Means by Policy Reform. In: Williamson, John (ed.): Latin American Readjustment: How Much has Happened. Washington: Institute for International Economics, 1989.

YANO, N. M.; MONTEIRO, M. M. Mudanças institucionais na década de 1990 e seus efeitos sobre a produtividade total dos fatores. In: XXXVI Encontro Nacional de Economia, 2008, Salvador, dez. 2008.

Ednilson Silva Felipe. Professor do Departamento e do Mestrado em Economia da Universidade Federal do Espírito Santo. Doutor em Economia pelo Instituto de Economia da Universidade Federal do Rio de Janeiro (2010). Mestre em Teoria Econômica (2006) e graduado em Ciências Econômicas (2003) pela Universidade Federal do Espírito Santo. Especialista em Controladoria e Finanças Empresariais pela Universidade Federal de Lavras/MG (2007). ednilsonfelipe.ufes@gmail.com

Juliano Vargas. Doutorando em Economia pela Universidade de Brasília (UnB). Mestre em Economia (2015) e Bacharelado em Ciências Sociais (2016) pela Universidade Federal do Espírito Santo. Bacharelado em Ciências Econômicas pela Universidade Federal do Rio Grande do Sul (2012). Bacharelado e Licenciatura em Educação Física pela Universidade de Caxias do Sul (2007). MBA em Gestão Estratégica em Comércio Exterior pela Universidade Cândido Mendes. Tem interesse na área de Economia, com ênfase em Teoria Econômica e Economia Política. brazil.juliano@gmail.com 